\title{
RASHOMON DAN PEREMPUAN TUA DALAM RASHOMON: ISU PLAGIARISME
}

\author{
Akhmad Fatoni \\ Kajian Sastra dan Budaya, FIB, Universitas Airlangga \\ Email: fatoni.akhmad@gmail.com
}

\begin{abstract}
Abstrak
Plagiarisme merupakan sebuah tindakan amoral dalam dunia kepenulisan. Namun sejauh apa batasan sebuah tulisan disebut plagiat atau nonplagiat, hal itulah yang sampai masih belum diberikan patokan. Berbicara plagiarisme tentu masuk wilayah orisinilitas sebuah tulisan, akan tetapi ketika berbicara orisinilitas tentu seperi hal yang sangat mustahil dilakukan. Sebab setiap tulisan pasti terdapat gagasan-gasasan orang lain di dalamnya. Dalam dunia sastra Indonesia, isu plagiarisme sudah sering kali terjadi dan diungkapkan. Kejadian itu beberapa tahun yang lalu kembali muncul dalam sastra koran, tepatnya pada tahun 2011 lalu. Kasus itu menimpa seorang penulis muda, Dadang Ari Murtono (DAM), atas tudingan bahwa cerpennya Perempuan Tua dalam Rashomon merupakan plagiasi dari cerpen Rashomon karya Rynosuke Akutagawa, cerpenis asal Jepang. Tulisan ini mengkaji kasus tindak plagiarisme tersebut dengan menggunakan metode kajian sastra bandingan dan menggunakan teori postmodernisme. Tujuan kajian ini untuk mengungkap apakah memang yang dilakukan DAM tindakan plagiarisme atau fenomena tersebut hanya politik sastra. Selain itu, juga membuka wacana baru bahwa bentuk tulisan seperti yang dilakukan DAM termasuk dalam kategori pencurian atau sebuah tawaran baru dalam dunia kepenulisan.
\end{abstract}

Kata Kunci: plagiarisme, postmodernisme, sastra bandingan, politik sastra.

\begin{abstract}
Plagiarism is an immoral act in the world of authorship. But the extent to which the boundaries of a writing is called plagiarism or nonplagiat, that is what until it has not been given a benchmark. Speaking of plagiarism necessarily belongs to the originality of a writing, but when speaking of originality is certainly something that is impossible to do. For every writing must be the ideas of others in it. In the world of Indonesian literature, the issue of plagiarism has often occurred and is expressed. The incident a few years ago re-emerged in newspaper literature, precisely in the year 2011 ago. The case happened to a young writer, Dadang Ari Murtono (DAM), on the accusation that the short story in Rashomon Old Woman is a plagiarism of Rashomon's short story by Rynosuke Akutagawa, Japanese cerpenis. This paper examines the case of such plagiarism using the method of
\end{abstract}


comparative literature study and using the theory of postmodernism. The purpose of this study is to uncover whether or not the DAMs act of plagiarism or the phenomenon is only political literature. In addition, it also opens up a new discourse that forms of writing as do DAM included in the category of theft or a new offer in the world of authorship.

Keywords: plagiarism, postmodernism, comparative literature, literary politics.

\section{PENDAHULUAN}

Berbicara soal plagiarisme memang bukan persoalan yang bisa diulas dalam tulisan singkat (baca: bisa dibaca sekali duduk). Namun setidaknya ulasan singkat ini mampu memberi sedikit pencerahan. Sebab tulisan-tulisan yang menyoal tentang itu bisa membuat perdebatan yang panjang-lebar, seperti yang telah banyak tercatat dalam perjalanan sastra Indonesia. Akan tetapi, berbicara perihal plagiarisme, secara tidak langsung juga membincangkan perihal orisinilitas.

Berbicara orisinilitas, sama halnya dengan berniat mencari jarum dalam tumpukan jerami. Namun, bukan berarti permasalahan plagiarisme bisa dibiarkan begitu saja. Sebab plagiarisme merupakan salah satu tindakan melanggar hukum (baca: hak cipta) yang sudah ditentukan dalam UU nomor 19 tahun 2002. Tentunya juga sebagai tindakan yang kurang menghargai kekayaan intelektual. Akan tetapi dalam ranah postmodernisme, tentu plagiarisme merupakan hal yang amat bertolak belakang (Laksana, 2011; Toha-Sarumpaet, 2010).

Menyikapi perihal tersebut, tulisan ini disajikan untuk mendedah persoalan yang beberapa waktu lalu ditempakan kepada Dadang Ari Murtono (selanjutnya disebut DAM). Namun kenapa kajian ini perlu ditulis? Karena kasus itu serta merta dianggap selesai dan tidak diperdebatkan lagi setelah Putu Fajar Arcana menyatakan pencabutan atas PTR pada Minggu, 6 Pebruari 2011. Setidaknya tulisan ini berusaha menjawab pertanyaan-pertanyaan apakah benar apa yang 
dilakukan DAM tersebut sebuah plagiarisme. Dalam tulisan ini, mencoba melakukan pemaknaan menggunakan sudut pandang postmodern.

Memang soal pemaknaan karya sastra, itu hak dari pembaca, seperti yang dikemukakan oleh Prodopo (2003: vii) dalam pengantar bukunya Beberapa Teori Sastra, Metode Kritik dan Penerapannya bahwa "kritik ilmiah dengan sistematika dan metodenya, terutama dipusatkan pada penerangan karya sastra untuk pemahaman, sehingga kritik sastra ilmiah merupakan sebuah upaya perebutan makna (rekuperasi) atau pemberian makna sastra." Akan tetapi, ada beberapa orang yang mengatakan kasus yang dilakukan DAM bukan plagiat. Namun ulasan yang terperinci tidak ditulis dan dibiarkan hilang begitu saja. Maka dari itu, tulisan ini ditujukan memberi ulasan secara tertulis dan juga sebagai sandingan dengan tulisan yang mengatakan kasus DAM sebagai plagiat. Selanjutnya, biarkan pembaca yang melakukan rekuperasi sendiri atas kasus DAM sebagai plagiarisme atau penerapan teknik postmodernisme.

Tulisan ini berpijak dari cerpen Perempuan Tua dalam Rashomon (selanjutnya disebut PTR) dan cerpen Rashomon karya Akutagawa Ryunosuke (cerpenis Jepang) dalam judul buku yang sama, terbitkan Kepustakaan Populer Gramedia (KPG) tahun 2008 hasil terjemahan Bambang Wibawarta.

\section{Plagiarisme atau Politik Sastra}

Sikap plagiarisme yang ditudingkan kepada DAM atas cerpennya PTR, seolah-olah ada semacam politik sastra yang melatarbelangi kejadian tersebut. Hal itu seperti yang telah disebut sebelumnya, yakni kasus dianggap selesai setelah pihak Kompas telah menyatakan pencabutan atas cerpen PTR. Sungguh miris. Menelisik kembali kasus tersebut, memang ada beberapa kalimat dan paragraf yang sama persis dengan cerpen Rashomon-nya Akutagawa. Hal itulah yang menjadi bahan perdebatan di dunia maya (sebut saja media online: facebook, twitter, ataupun blog pribadi), bahkan merembet pada media cetak: koran. Perdebatan cukup sengit. Akan tetapi, apakah benar PTR yang ditulis DAM 
memang plagiat atau hanya semacam ada politik sastra di baliknya? Tentunya untuk menjawab persoalan itu perlu diketahui batasan sebuah karya dikatakan sebagai plagiat atau bukan.

Konsep plagiat dalam seni dan ilmu memiliki perbedaan, walaupun berbedaan di antaranya hanya sedikit karena pada intinya mengusung makna yang sama, yakni mengambil pemikiran ataupun karya orang lain menjadi karyanya sendiri. Plagiat secara umum (seni) dalam KBBI (2007: 881) adalah pengambilan karangan (pendapat dsb) orang lain dan menjadikannya seolah-olah karangan (pendapat dsb) sendiri. Sedang menurut Brian Martin dari American Historical Association: "Plagiarisme paling jelas terjadi ketika seorang menyalin ungkapan atau deretan kalimat-kalimat dari suatu karya yang sudah diterbitkan tanpa memakai tanda kutip, tanpa memberikan penghargaan kepada sumber, atau kedua-duanya".

Sedangkan plagiarisme dalam dunia akademik (baca: ilmu) menurut Sujinah (2014: 63) dibagi menjadi 2, yaitu sengaja dan tidak disengaja. Plagiarisme dalam bentuk kecurangan (baca: sengaja) meliputi 6 hal, yaitu:

1. Menggunakan atau mengambil teks, data, struktur, gagasan utama, materi audio atau visual orang lain, software dan kode program atau gagasan orang lain tanpa memberikan pengakuan terhadap sumber secara benar dan lengkap.

2. Tidak menunjukkan secara jelas dalam teks, misalnya dengan tanda kutipan atau penggunakan lay-out tertentu, bahwa kutipan literal atau yang mendekati telah dimasukkan dalam karyanya.

3. Memarafrase (mengubah kalimat orang lain ke dalam susunan kalimat sendiri tanpa mengubah idenya) isi dari teks orang lain tanpa rujukan terhadap sumber. 
4. Menggunakan teks yang pernah dikumpulkan sebelumnya, atau menggunakan teks yang mirip dengan teks yang pernah dikumpulkan sebelumnya untuk tugas sebuah mata kuliah.

5. Mengambil karya orang lain dan dijadikan sebagai karyanya sendiri.

6. Mengumpulkan paper yang dibuat dengan cara membeli atau membayar orang lain untuk membuatnya.

Sedangkan menurut Sujinah (2014: 63) plagiarisme yang tidak disengaja yakni tindak plagiarisme karena tidak diketahui disebut inadvertent plagiarism (plagiarisme tidak sengaja). Plagiarisme tidak disengaja, sanksinya sama dengan plagiarisme yang disengaja.

Pada tataran inilah, segala sesuatu menjadi semakin rumit. Sebab sangat sulit untuk menjaga tulisan agar tidak sampai menyamai persepsi atau pendapat yang telah ditulis orang lain. Maka dari itu, seperti yang telah disebut diawal, berbicara orisinilitas seperti mencari jarum dalam tumpukan jerami. Apalagi jika kasusnya kita terlahir belakangan, tentu segala sesuatu itu sudah pernah ditulis atau dicetuskan oleh orang lain.

Maka dari itu, jika berusaha mencari sesuatu yang benar-benar asli sungguh sangat mustahil. Setiap teks pasti menyimpan teks lain di dalamnya. Jika dikembalikan pada konteks DAM, tentu hal ini menjadi sesuatu perenungan tersendiri dan akan menjadi topik utama dalam tulisan ini.

Selanjutnya tentang politik sastra. Politik menurut KBBI (2007: 886) cara bertindak (dalam menghadapi atau menangani suatu masalah) atau kebijaksanaan. Sedangkan Sastra menurut Quinn (1992: 43) ialah "tulisan yang khas, dengan pemanfaatan kata yang khas, tulisan yang beroperasi dengan cara yang khas dan menuntut pembacaan yang khas pula." Berdasarkan atas pendapat tersebut, bisa disimpulkan bahwa politik sastra yakni cara dalam menghadapi atau menangani suatu masalah yang muncul dalam dunia sastra. 
Atas dasar itulah saya menduga, kasus DAM itu antara plagiarisme dan politik sastra. Pada saat itu, ada dua pandangan: mengatakan plagiarisme dan bukan plagiarisme. Namun pandangan itu tidak membentuk oposisi binner, sebab pandangan yang mengatakan tindakan yang dilakukan DAM dengan PTR bukan plagiarisme lebih cenderung memilih diam dan membiarkan masalah tersebut, hanya ada beberapa yang menuliskannya.

\section{Estetika Posmodern}

Postmodernisme kali pertama muncul dicetuskan pada tahun 1930 pada bidang seni oleh Federico de Onis. Lalu setelah itu, bermunculan tokoh-tokoh lain sebut saja, Jean Francois Lyotard, Geldner, Derrida, Foucault, Bauldrilard, David Graffin, Gidden, Habermas (Wikipedia). Namun dalam kajian ini, akan lebih berfokus pada lima estetika postmodern adalah; pastiche, parodi, kitsch, camp, dan skizofrenia (Pialang, dalam Saptono, 2011). Akan tetapi pada kajian ini, hanya digunakan Pastiche, Parodi, dan Skizofrenia. Selanjutnya Saptono (2011) dengan mengutip beberapa tokoh dalam tulisannya, Sajian Komposisi Karawitan Sebuah Kategori Contoh dalam Wacana Estetika Postmodern, menjelaskan secara detail sebagai berikut:

\section{Pastiche}

Sebagai karya yang mengandung unsur-unsur pinjaman, pastiche memunyai konotasi negatif sebagai miskin kreativitas, orsinilitas, keotentikan, dan kebebasan. Pastiche sering kali dikaburkan dengan kategori-kategori estetik yang sejenis: parodi, burlesque, travestry, plagiarisme, kutipan, alusi atau satire. Perbedaan antara pastiche dan parodi terletak pada 'model relasinya' dengan teks atau karya yang menjadi rujukannya. Sedangkan penekanan parodi pada menggali, mencari, dan menonjolkan 'perbedaan-perbedaan' dengan teks rujukannya. 
Dengan demikian pastiche mengambil bentuk-bentuk teks atau bahasa estetik dari berbagai fragmen sejarah, sekaligus mencabutnya dari 'semangat jamannya', dan menempatkannya kedalam konteks 'semangat jaman' masa kini. Oleh sebab itu pastiche adalah satu bentuk parodi terhadap sejarah. Menurut Eco (1973) dalam Piliang (1999:150), ia merupakan suatu “...perang terhadap sejarah...sebab, sejarah tidak dapat diulangi.

\section{Parodi}

Robert Venturi, Denis Scott Brown \& Steven Izenour dalam tulisannya Learning From Las Vegas menyatakan;

"Substansi bagi seorang penulis tidak hanya melingkupi realitas-realitas yang ia anggap ditemukan; substansi yang mengandung lebih dari sekedar realitas-realitas ini yang disediakan untuknya oleh literatur dan idiomidiom dari zamannya sendiri dan oleh citraan-citraan yang masih memiliki vitalitas dalam literatur masa lalu. Berkaitan dengan gaya, seorang penulis dapat mengekspresikan perasaannya tentang substansi ini dengan cara imitasi-bila substansi ini mendapat tempat di dalam dirinya, atau dengan cara parodi" (Venturi dkk, 1989, dikutip dalam Piliang, 2003:213).

Parodi adalah satu bentuk dialog antar teks dan sebagai oposisi atau kontras. Ada dua pengertian tentang Parodi, pertama parodi salah satu bentuk dialog antara satu teks bertemu dan berdialog dengan teks lainnya. Kedua; tujuan dari parodi adalah untuk mengekspresikan perasaan tidak puas, tidak senang, tidak nyaman berkenaan dengan intensitas gaya atau karya masa lalu yang dirujuk. Parodi juga merupakan salah satu bentuk imitasi yang selalu mengambil keuntungan dari teks yang menjadi sasaran (kelemahan, kekurangan, keseriusan atau bahkan kemasyuran), makanya parodi sebagai satu bentuk wacana selalu memperalat wacana pihak lain untuk menghasilkan efek makna idealitas dan nilai estetika yang dibangunnya.

\section{Skizofrenia.}

Skizofrenia adalah sebuah istilah psikoanalisis yang pada awalnya digunakan untuk menjelaskan fenomena psikis dalam diri manusia. Namun 148 | ISSN: 22477-5150 http://journal.unesa.ac.id/index.php/jpi 
demikian dalam perkembangannya wacana ini berkembang dan digunakan untuk menjelaskan fenomena yang lebih luas, termasuk di dalamnya peristiwa bahasa (Lacan), fenomena sosial ekonomi, sosial politik (Deleuze dan Guattari), dan fenomena estetika (Jameson) (Piliang, 2003:227).

Berdasarkan atas tiga pilar tersebut, kedua cerpen tersebut akan dibandingkan untuk mencapai titik temu (baca: jawaban atas polemik plagiarisme DAM).

\section{Tawaran PTR dan Rashomon}

Pada dasarnya, kedua cerpen tersebut masih memiliki persamaan, yakni sama-sama bersumber pada topik kemunduran kota Kyoto setelah tertimpa bencana beruntun. Namun pada kedua cerpen tersebut ada tawaran gagasan yang berbeda. Kajian ini bertujuan (meminjam istilah Hutomo, 1993: 9): "memperkokoh keuniversalan konsep-konsep keindahan universal dalam sastra."

Cerita dalam PTR, DAM condong pada tokoh perempuan tua. Di mana ia menjadikan tokoh perempuan tua dalam cerita sebagai tokoh utama. Sedangkan cerita dalam Rashomon berbanding terbalik, pusatnya pada Genin.

Berangkat dari perbedaan itulah, kedua cerpen ini menawarkan gagasan yang berbeda. Jika ditilik dari alur, kedua cerita ini memiliki perbedaan yang sangat mencolok. Di mana pada PTR, DAM menjalankan ceritanya melalui tokoh perempuan tua, sedangkan pada Rashomon, Akutagawa menjalankan cerita melalui tokoh Genin. Segala gambaran, setting, watak, dan suasana akan lebih condong pada pusat (baca: tokoh) masing-masing yang notabene berbeda. Pada tataran intrinsik yang berbeda itulah akhirnya masing-masing cerpen memiliki unsur ekstrinsik yang berbeda pula.

Demi pembacaan ulang, PTR dibagi menjadi 20 bagian yang nanti dibandingkan dengan Rashomon untuk mempermudah menilik tawaran gagasan 
masing-masing cerpen. Dari 20 bagian itu, dalam ulasan akan dibagi menjadi 2: teks yang sama dan yang tidak ada dalam teks Rashomon.

\section{Teks yang Sama dengan Rashomon}

Bagian 1 dalam PTR terdiri dari 4 kalimat (Murtono, 2011). Bagian ini, DAM merombak ulang paragraf ke-14 pada Rashomon (Ryonosuke, 2008: 6) dan juga ia memulai melawan Akutagawa (yang tokoh utamanya Genin) dengan mengubah tokoh utama perempuan. Kalimat pertama, DAM mengubah dengan kalimatnya sendiri. Kalimat kedua, ia hampir membiarkan sama persis, hanya ada perbedaan kata penghubung "yang" dan "dan", juga menambahkan imbuhan "ber-" pada kata "bertubuh". Kalimat ketiga, sama persis. Dan kalimat keempat, DAM mengubah sudut pandang dari Ryonosuke yang masih ragu-ragu menggambarkan mayat seorang perempuan.

Bagian 2 dalam PTR terdiri dari 5 kalimat (Murtono, 2011). Bagian ini, DAM merombak ulang paragraf ke-3 pada Rashomon (Ryonosuke, 2008: 2). Pada paragraf ini, DAM masih tetap berusaha membentuk latar cerita yang tidak jauh dari cerpen asalnya (Rashomon), DAM berusaha menciptakan penggambaran sendiri dan tidak segan mengeluarkan idenya untuk membuat kontruksi baru dalam ceritanya. Akan tetapi, ia mengeluarkan beberapa kata pada kalimat ketiga, kalimat keempat sama persis, dan pada kalimat kelima, pada frasa terakhir.

Bagian 3 dalam PTR terdiri dari 6 kalimat (Murtono, 2011). Bagian ini, merupakan kelanjutan bagian 2 yang sama-sama menanggapi paragraf ke-3 pada Rashomon (Ryonosuke, 2008: 2). DAM hanya pada kalimat ke-6 yang tidak memunculkan data dari Rashomon, kalimat yang ia munculkan sebagai tanggapan dari suasana yang diceritakan Rashomon. Kalimat ke-5, DAM hanya mengambil latar dari Rashomon: senja (waktu) dan suasana menjadi "teramat" menyeramkan (suasana), akan tetapi DAM menambahkan kengerian dengan menambahkan kata "teramat. Kalimat ke-4, ia menanggapi sikap Ryonosuke 
pada kalimat ini dengan kata penghubung "dan" dan kata "bukan perkara aneh", untuk mencoba membuat perlawanan dengan ide Ryonosuke. Kalimat ke-3, DAM menambahkan kekuatan biar lebih mencekam dengan penambahan objek: musang, burung punai, dan penjahat. Sedangkan kalimat kedua, merupakan lanjutan dari kalimat pertama, di mana semuanya sama persis. DAM hanya melawan dengan memunculkan kata penghubung "dengan", sungguh amat detail hanya dengan kata penghubung ia sudah menolak gagasan.

Bagian 8 dalam PTR terdiri dari 8 kalimat (Murtono, 2011) yang merupakan tanggapan dari paragraf 9-13 pada Rashomon (Ryonosuke, 2008: 4-6). Jika dilihat dari kesamaan, data yang tidak mengalami perombakan (sebut sama persis dalam teks dan konteks): berpakaian, mayat laki-laki, perempuan, berserakan, di lantai, boneka-boneka dari tanah, mulutnya mengangah, dan pernah hidup, serta ada 1 kata yang diubah dalam PTR yakni membayangkan, kalau dalam Rashomon, bayangkan. Sedangkan yang membuat beda (baca: tawaran) yakni, pada PTR digunakan DAM untuk menceritakan perempuan tua, sedangkan dalam Rashomon, Akutagawa untuk menceritakan Genin.

Bagian 12 dalam PTR terdiri dari 3 kalimat (Murtono, 2011) yang merupakan tanggapan dari paragraf 16 pada Rashomon (Ryonosuke, 2008: 6-7). Pada bagian ini, DAM hanya memberi pengatar pada kalimat pertama, selebihnya sama persis dengan data Rashomon sampai kalimat 2. Sedangkan pada kalimat ketiga, DAM memunculkan persepsi sendiri. la memunculkan semacam ingatan si tokoh perempuan tua. Akan tetapi, ia gagal sebab tidak menyebutkan sedang ingat siapa. Jika ia berniat bermain simbol, ia tidak memunculkan simbol lainnya, sehingga tidak ada korelasi simbol seperti gagasan Ferdinand de Saussure perihal simbol: korelasi simbol.

Bagian 13 dalam PTR terdiri dari 8 kalimat (Murtono, 2011) yang merupakan tanggapan dari paragraf 17-21 pada Rashomon (Ryonosuke, 2008: 78). Pada bagian ini, DAM sangat terlihat merombak gagasan Akutagawa, ia hanya 
mengeluarkan data yang secara teks dan konteksnya sama, yakni diucapkan oleh Genin pada perempuan tua (nenek): ia terlonjak bagai dilontarkan dengan ketapel. "Hai mau ke mana kau?" hardik Genin seraya mencengkeram tangan si nenek yang bermaksud melarikan diri.

Bagian 14 dalam PTR terdiri dari 3 kalimat (Murtono, 2011) yang merupakan tanggapan dari paragraf 21-22 pada Rashomon (Ryonosuke, 2008: 89). Gagasan dari 2 paragaf itu hanya dimunculkan dalam kalimat 1 dan 2, sedangkan kalimat 3 DAM berusaha menggambarkan psikologi tokoh perempuan tua.

Bagian 15 dalam PTR terdiri dari 4 kalimat (Murtono, 2011) yang merupakan tanggapan dari paragraf 23 pada Rashomon (Ryonosuke, 2008: 9). Di mana keduanya sama persis, yakni dialog Genin kepada perempuan tua (nenek).

Bagian 16 dalam PTR terdiri dari 11 kalimat (Murtono, 2011) yang merupakan tanggapan dari paragraf 25-27 pada Rashomon (Ryonosuke, 2008: 9-10). Kalimat pertama DAM mengambil pada paragraf 25 (perkataan nenek) namun ia menghilangkan satu kalimat "aku mencabuti rambut" pada hal ini, DAM merasa kalimat yang ditulis Akutagawa mubadir, sehingga ia menghilangkannya. Kalimat kedua merupakan kreasi DAM membaca data dari Rashomon. Dan barulah dari kalimat 3 sampai 11, itu sama persis yang notabene itu perkataan nenek.

Bagian 17 dalam PTR terdiri dari 3 kalimat (Murtono, 2011) yang merupakan tanggapan dari paragraf 29-30 pada Rashomon (Ryonosuke, 2008: 910). Bagian ini semuanya sama persis, akan tetapi 3 kalimat dalam PTR merupakan hasil penggalan-penggalan dari Rashomon.

Bagian 18 dalam PTR terdiri dari 4 kalimat (Murtono, 2011). yang merupakan tanggapan dari paragraf 30-31 pada Rashomon (Ryonosuke, 2008: 910). Kalimat 1 dan 2 sama persis, yakni diambil dari perkataan Genin. Sedangkan 3-4, ini tidak ada. DAM mengolahnya dari pagaraf 31. 


\section{Teks yang Tidak Ada dalam Rashomon}

Pada data kedua ini, yakni berisi data dari PTR yang tidak sama secara teks dengan Rashomon. Akan tetapi, sedikit banyak masih memiliki kesamaan secara kontekstual. Kesamaan itu dikarenakan PTR dibuat untuk merespon Rashomon, sehingga bisa dikatakan PTR lahir bukan dari kekosongan. PTR lahir dari kegelisahan DAM membaca Rashomon yang ditulis oleh Akutagawa. Hal itu juga dijelaskan oleh Zuber Usman, B.A. (dalam Prodopo, 2003: 33) melalui bukunya:

"Hasil pekerjaan pengarang dan penyair itu dinamakan kesusastraan atau seni sastra. Kesusastraan adalah cabang dari kesenian dan kesenian seperti itu kita maklum bagian dari kebudayaan.

Kesusastraan pokok katanya (castra. Skt)= tulisan atau bahasa; su (Skt): indah, bagus... susastra= bahasa yang indah, maksudnya hasil ciptaan bahasa yang indah atau seni bahasa. Kesusastraan mendapat awalan dan akhiran (ke-an). Yang dimaksud dengan kesusastraan ialah hasil kehidupan jiwa yang terjelma dalam tulisan atau bahasa tulis yang menggambarkan atau mencerminkan peristiwa kehidupan masyarakat atau anggota masyarakat."

Seperti pendapat Zuber dalam kutipan tersebut, PTR mencerminkan peristiwa kehidupan masyarakat atau anggota masyarakat. Akan tetapi penangkapan realita DAM bukan secara langsung, melainkan dari cerpen Rashomon karya Akutagawa.

Data yang tidak memiliki kesamaan ini, meliputi bagian $4,5,6,7,9,10$, 11, 19, dan 20. Bagian ini memunculkan sebuah perlawanan yang bertolak belakang dari data sumbernya (Rashomon). Pemunculan bagian-bagian ini memihak pada tokoh perempuan tua, kalau dalam Rashomon tokoh nenek dimunculkan untuk membuat suasana semakin mendukung gagasan yang mau disampaikan oleh DAM. Seperti ditunjukkan pada bagian 4, perempuan itu digambarkan seperti monyet. Padahal pada Rashomon tidak ada penggambaran itu.

Pada bagian 9, DAM juga memiliki pemikiran kreatif di mana tokoh perempuan tua berusaha mencari uang dari mayat-mayat. Tetapi, ia juga 
menentangnya sendiri di akhir paragraf. Selanjutnya pada paragraf 10 dan 11 , DAM memainkan data dalam Rashomon sehingga muncul penafsiran baru, yakni perempuan itu ingat dengan ajaran ayahnya membuat cemara dari rambut. Bekal dari itulah, akhirnya perempuan tua memilih tinggal dan berharap akan selalu ada mayat untuk dicabuti rambutnya biar ia tetap bisa hidup dari hasil menjual cemara dari rambut mayat-mayat yang selalu dibuang di menara tempat ia tinggal.

Selanjutnya untuk mengakhiri cerita PTR, DAM membuat bagian 19 dan 20 yang benar-benar dibuat berlawanan. Jika dalam Rashomon setelah Genin merampas baju, maka ia pergi, dan nenek berusaha melihat Genin dari balik jendela. Sedangkan DAM, menyelesaikan ceritanya dimulai dengan hal yang sama yakni merampas pakaian dan memukul si perempuan tua. Kemudian meninggalkannya. Bedanya, perempuan tua dengan tokoh nenek yakni perempuan tua itu melihat mayat-mayat (tidak melihat jendela) dan berkata kalau menjadi mayat itu damai sekali. Tidak perlu mengurusi masalah perut. Sehingga ia ingin seperti mayat-mayat itu. Sungguh cara penyelesaian yang amat kontemplatif. Cara pandang yang tidak wajar.

Pengupasan data tersebut, bisa ditilik tawaran gagasan yang mau disodorkan DAM melalui ceritanya dan juga tawaran Rashomon yang dituduhkan dipalgiat oleh DAM.

\section{SEMACAM TAKRIF}

Berdasarkan dari analisis kedua data (sesuai dengan batasan kajian bandingan), memang terdapat banyak sekali kesamaan. Hal itu secara lapis luar pun sudah mampu ditebak, yakni hanya 9 dari 20 bagian yang tidak memiliki kesamaan secara tekstual. Akan tetapi, 9 data tersebut menunjukkan sebuah kegelisahan yang dialami oleh DAM. Kegelisahan setelah melakukan pembacaan terhadap Rashomon karya Akutagawa. Dan titik didih kegelisahan DAM akhirnya lahir menjadi cerpen PTR, dan tercermin dalam 9 bagian tersebut. Sedangkan 
pemunculan 11 bagian yang memiliki kesamaan dengan Rashomon yakni sebagai timbal-balik secara langsung.

Namun public sastra Indonesia (penulis ataupun pembaca) ada yang masih belum menerima cara yang disodorkan oleh DAM. Memang tidak semua menolak, akan tetapi mereka lebih memilih diam atau membiarkan permasalahan itu menjadi dingin dengan sendirinya. Akan tetapi, tindakan semacam ini tentu membahayakan. Sebab akan mencipta literature bahwa setiap tawaran yang serupa (seperti DAM menyuguhkan PTR) akan serta-merta dianggap sebagai plagiarisme. Hal itulah yang memantik fenomena: publik sastra tidak bisa menerima. Pembacaan awal, dilakukan oleh Sungging Raga, ketika PTR dimuat dalam harian Lampung Pos. Kemudian disusul pembacaan oleh Bamby Cahyadi.

Pembacaan yang dilakukan oleh Sungging Raga dan Bamby Cahyadi yakni dengan cara data yang disodorkan DAM (data yang sama persis dengan Rashomon) dipadupadankan dengan definisi plagiarisme. Sehingga hasil pembacaan sinkron dan menyatakan PTR hasil dari plagiarisme. Sedangkan menurut Brian Martin dari American Historical Association: "Plagiarisme paling jelas terjadi ketika seorang menyalin ungkapan atau deretan kalimat-kalimat dari suatu karya yang sudah diterbitkan tanpa memakai tanda kutip, tanpa memberikan penghargaan kepada sumber, atau kedua-duanya".

Berdasarkan pendapat Brian tersebut, beberapa data DAM jelas menyalahi aturan pertama karena setiap kalimat atau paragraf yang diambilnya dari Rashomon tidak sedikitpun memakai tanda kutip, kecuali dialog. Sedangkan pada aturan kedua, DAM memunculkan penghargaan tersebut dengan adanya catatan kaki. Akan tetapi, penulisan catatan kaki tersebut memang tidak sesuai dengan kaidah pengutipan.

Pada titik inilah sebenarnya jalan menuju tawaran DAM dalam PTR untuk ditelaah. DAM menciptakan sesuatu yang baru. Dan ia tidak melanggar aturan 
kedua, sebab masih menghormati dan memberi penghargaan terhadap karya yang menginspirasinya (karya Akutagawa) melalui catatan kaki yang ditulisnya.

Namun pada saat cerpen PTR dimuat di Kompas (30/1/2011) catatan tersebut dihilangkan, berbeda pada saat cerpen tersebut dimuat di Lampung Pos (5/12/2010). Tidak munculnya catatan tersebut dalam Kompas yang notabene sebagai koran nasional dan memiliki kredibilitas yang tinggi memantik persoalan yang mampu mengubur Lampung Pos yang pernah memuat catatan kaki. Hal itu, akhirnya menciptakan polemik.

Lepas dari masalah pemuatan di dua media tersebut, tentu kehadiran catatan kaki dalam PTR tidak bisa diabaikan begitu saja. Sebab DAM dengan memunculkan catatan itu berarti ia semacam membuat pernyataan tersirat akan tawaran barunya. Tentu tawaran itu adalah bentuk modern yang berusaha ia terapkan.

Sedangkan kata modern menurut KBBI memiliki arti "terbaru"; "mutakhir"; atau "sikap dan cara berpikir serta cara bertindak sesuai dengan tuntutan jaman." Dan menurut Prawiro perihal karya seni modern "sifat-sifat yang dimaksudkan adalah ciri-ciri yang menunjukkan karya seni yang berbeda dengan kebiasaan sebelumnya sehingga memperlihatkan hal baru." Berdasarkan hal itu, ketika membandingkan kedua cerpen tersebut, tidak ditemukan kebaruan, yang ada hanya pengubahan sudut pandang dan penceritaan.

Akan tetapi, dari cerpen PTR yang memunculkan teks-teks dalam Rashomon menunjukkan bahwa DAM berusaha melakukan kilas balik. Hal itu senada dengan kaidah postmodern. Postmodern menurut Charles Jencks (dalam Gresz) "Postmodenisme adalah campuran antara macam-macam tradisi dan masa lalu. Postmodern adalah kelanjutan dari modernisme, sekaligus melampaui modernism."

Berdasarkan dari pendapat Charles tersebut, tawaran gagasan DAM melalui PTR adalah sebuah eksplorasi yang bisa dikategorikan dalam aliran postmodern. Selain itu, jika karya DAM dilihat dari segi estetika postmodern 156 | ISSN: 22477-5150 http://journal.unesa.ac.id/index.php/jpi 
sangatlah sesuai. Hal itu ditunjukkan dari data yang ada dalam PTR yang sangat banyak data dari Rashomon, sesuai dengan estetik postmodern: Patiche, yakni miskin kreativitas.

Tidak hanya itu, jika dilihat dari estetik parodi, PTR merupakan sebuah semangat DAM atas ketidakpuasan atas membaca Rashomon. Teknik parodi akhirnya dipilih DAM dengan pergantian tokoh utama. DAM sangat terlihat membela si perempuan tua yang memang tidak punya harapan. Akan tetapi dalam cerpennya, ia memberikan sebuah harapan dan menceritakan kalau ia dulunya seseorang yang bisa dibilang berkecukupan. Di mana penggambaran itu, sebenarnya pembalikan dari Rashomon yang semua cerita itu dimiliki oleh Genin.

Tawaran yang dimunculkan DAM, yang notabene sebagai respon ketidakpuasan (unsur psikologi DAM selaku pengarang) akhirnya tercermin dalam cerpen. Hal itu, nampak dari gagasan sang tokoh perempuan tua ketika melihat mayat-mayat dan akhirnya memutuskan tinggal di menara. Tentu kekhawatiran yang berlebihan itu, membuat ia berani tidur dan bergumul dengan mayat. Pada realitanya, manusia memiliki sindrom pada mayat. Hal itu, bisa dilihat sikap yang diberikan pada kamar mayat di rumah sakit. Dan ketika si tokoh perempuan tua akhirnya memungkas ketakutannya dengan kontemplasi mendalam tatkala ia dirundung musibah (dihajar Genin dan dirampas pakaiannya) ia melihat betapa nikmatnya menjadi mayat yang tidak pernah takut lapar dan dibebani kebutuhan manusiawi.

Gagasan dan teknik yang dilakukan DAM, sehingga dari 11 dari 20 bagian memiliki kesamaan dengan Rashomon Gagasan, merupakan penerapan dari estetik postmodern yakni skizofrenia. Teknik Skizofrenia yakni teknik memunculkan masa lalu (cerpen Rashomon) dalam PTR.

Tawaran yang dilakukan DAM merupakan sebuah tindakan postmodern, bukan plagiarisme. Hal itu dibuktikan DAM dengan memunculkan catatan kaki dalam cerpennya. Akan tetapi, tindakan seperti ini yakni miskin kreativitas 
(estetik postmodern: Patiche). Jadi, segala tuduhan yang sempat ditempakan kepada DAM yakni semata ada gerakan politik sastra. Maka dari itu, dari ulasan ini bisa disimpulkan bahwa tindakan yang dituduhkan kepada DAM semata hanya politik sastra. Politik sastra yang dilakukan yakni menggunakan asas plagiarisme, sehingga tuduhan tersebut amat kokoh dan membuat pihak Kompas akhirnya mencabut cerpen tersebut. Namun hal itu sebenarnya sudah menyalahi kaidah sastra menurut Quinn, karena pembacaan yang dilakukan terlalu kasar dan tidak menggunakan sudut pembacaan yang khas. Oleh karena itulah, jika kita dihadapkan pada karya sastra serupa PTR maka pembacaan kita yakni menggunakan kacamata postmodern.

\section{DAFTAR RUJUKAN}

Hutomo, Suripan Sadi. 1993. Merambah Matahari Sastra dalam Perbandingan. Surabaya: Gaya Masa.

Laksana, AS. 6 Pebruari 2011. Karena Njiplak Kerja Terhormat. Surabaya: Jawa Pos.

Prodopo, Rachmad Djoko. 2003. Prinsip-prinsip Kritik Sastra. Yogyakarta: Gadjah Mada University Press.

Ryunosuke, Akutagawa. 2008. Rashomon. Jakarta: Kepustakaan Populer Gramedia.

Sudjiman, Panuti dan Aart van Zoes (ed.). 1992. Serba-serbi Semiotika. Jakarta: Gramedia Pustaka Utama.

Sujinah. 2014. Pedoman Penulisan Tesis dan Artikel Ilmiah. Surabaya: Muhammadiyah University Press.

Toha-Sarumpaet, Riris K.. 2010. Pedoman Penelitian Sastra Anak. Jakarta: Yayasan Obor.

Tim Pusat Bahasa. 2007. Kamus Besar Bahasa Indonesia. Jakarta: Balai Pustaka. Harian Kompas, Minggu (30/1/2011). Harian Kompas, Minggu (6/2/2011). 
Akhmad Fatoni, Rashomon dan Perempuan Tua...(hal. 142 - 159)

Harian Jawa Pos, Minggu (6/2/2011).

Internet:

Murtono, Dadang Ari. 2011. Perempuan Tua dalam Rashomon. : Warteg

Cerpen. Diunduh Senin, 17 Maret 2014 dari http://wartegcerpen.blogspot.com/2011/04/perempuan-tua-dalamrashomon.html

Saptono. 2011. Sajian Komposisi Karawitan Sebuah Kategori Contoh dalam Wacana Estetika Postmodern. Denpasar: E-Jurnal ISI Denpasar. Diunduh 22 April 2014 dari http://repo.isi-dps.ac.id/730/. 